\title{
Further explanations for the eq. (3) in "Estimating the daily trend in the size of the COVID-19 infected population in Wuhan"
}

\author{
Qiu-Shi Lin', Tao-Jun Hu and Xiao-Hua Zhou ${ }^{1,3,4^{*}}$ (D
}

\begin{abstract}
To avoid possible confusions to the readers, we provide further explanations for the eq. (3) in the research article "Estimating the daily trend in the size of the COVID-19 infected population in Wuhan" published in the Infectious Diseases of Poverty.
\end{abstract}

In our study [1], we proposed a new model to estimate the daily trend in the size of the COVID-19 infected population in Wuhan. When discussing this article with our colleagues, we found that a little more explanations for eq. (3) are needed to avoid possible confusions to the readers.

In the Methods section, we let $x_{t}$ be the number of imported cases outside Hubei province on Day $t$, and derive a binomial model $x_{t} \sim \operatorname{Binomial}\left(N_{t}, p\right)$ if $t_{0}+d<t \leq$ $t_{0}+2 d$, and $x_{t} \sim \operatorname{Binomial}\left(N_{t}-N_{t-d}, p\right)$ if $t>t_{0}+2 d$. To make our model clearer, here $x_{t}$ is in fact the number of infected individuals that travelled from Wuhan to places outside Hubei province on Day $t-d$. However, among the 10940 confirmed cases in our data, 8546 (78.1\%) do not have information on the date of departure from $\mathrm{Wu}$ han, so the number of cases leaving Wuhan every day is unknown and hard to impute.

But the date of confirmation is available for each of the 10940 cases, so we use the cumulative number of

This comment refers to the article available at https://doi.org/10.1186/ s40249-020-00693-4.

* Correspondence: azhou@math.pku.edu.cn

${ }^{1}$ Beijing International Center for Mathematical Research, Peking University, Beijing 100871, China

${ }^{3}$ Department of Biostatistics, School of Public Health, Peking University, Beijing 100191, China

Full list of author information is available at the end of the article imported cases outside Hubei province as of Day $t$ as approximation of $X_{t}=\sum_{k=1}^{t} x_{k}$. Since the window from infection to detection is assumed as $d$ days in our model, the infected cases that left Wuhan before Day $t-d$ should be confirmed outside Hubei province before Day $t$, thus this approximation is reasonable and would not affect the conclusion in the paper.

\section{Acknowledgements}

None.

\section{Authors' contributions}

$Q L, T H$, and $X Z$ interpreted the results and wrote the manuscript. All authors read and approved the final manuscript.

\section{Authors' information}

Not applicable.

\section{Funding}

This research is supported by National Natural Science Foundation of China (Grant No. 82041023) and Zhejiang University special scientific research fund for COVID-19 prevention and control (Grant No. 2020XGZX016).

\section{Availability of data and materials}

All data and materials used in this work were publicly available.

Ethics approval and consent to participate

The ethics approval and individual consent was not applicable. 


\section{Consent for publication}

Not applicable.

\section{Competing interests}

The authors declare that they have no competing interests.

\section{Author details}

'Beijing International Center for Mathematical Research, Peking University, Beijing 100871, China. ${ }^{2}$ School of Mathematical Sciences, Peking University, Beijing 100871, China. '3 Department of Biostatistics, School of Public Health, Peking University, Beijing 100191, China. ${ }^{4}$ Center for Statistical Science,

Peking University, Beijing 100871, China.

Received: 3 August 2020 Accepted: 1 September 2020

Published online: 15 September 2020

\section{Reference}

1. Lin QS, Hu TJ, Zhou XH. Estimating the daily trend in the size of the COVID-

19 infected population in Wuhan. Infect Dis Poverty. 2020;9(1):69.

Ready to submit your research? Choose BMC and benefit from:

- fast, convenient online submission

- thorough peer review by experienced researchers in your field

- rapid publication on acceptance

- support for research data, including large and complex data types

- gold Open Access which fosters wider collaboration and increased citations

- maximum visibility for your research: over $100 \mathrm{M}$ website views per year

At BMC, research is always in progress.

Learn more biomedcentral.com/submissions 